\title{
REPRESENTASI AKHLAK DALAM NOVEL IAM SARAHZA KARYA HANUM SALSABIELA DAN RANGGA ALMAHENDRA SERTA RELEVANSINYA DENGAN PEMBELAJARAN BAHASA INDONESIA DI MADRASAH ALIYAH
}

\author{
(Representation Of Akhlak In Novel I'm Sarahza by Hanum Salsabiela And Rangga \\ Almahendra And Relevance With The Learning Of Indonesian Language In Madrasah \\ Aliyah)
}

\author{
Hilmi Mahya Mashuda, Elen Inderasari \\ Tadris Bahasa Indonesia, Institut Agama Islam Negeri Surakarta \\ Jalan Pandawa, Pucangan, Kartasura, Sukoharjo \\ Pos-el: hilmimahya5@gmail.com
}

(Naskah diterima tanggal 12 September 2019-Direvisi tanggal 5 November 2019—Disetujui tanggal 21

November 2019)

\begin{abstract}
This study aims to represent the teachings of Islam on the moral aspects in the novel Iam Sarahza by Hanum Salsabiela and Rangga Almahendra published by Republika in 2018. Researchers also relevant the results of research by learning Indonesian in Madrasah Aliyah. This type of research is library research that is research conducted by collecting various literatures. Data collection techniques used are reading and note taking techniques. The validity of the data is obtained by using theory triangulation by collecting various relevant theories and then the researcher draws his conclusions, the researcher uses the perspective of more than one theory to discuss the problems examined in the form of intrinsic elements of literary works and Islamic teachings. the data analysis technique used is structuralism which is suitable for interpreting or describing Islamic teachings implicit in novel intrinsic elements. the results showed that the moral values contained in this novel include morals such as (1) polite, (2) sincere, (3) patient, (4) sympathizing orphans, (5) thanksgiving, (6) almsgiving, (7) advised, (8) throwing (9) trash in its place and (10) serving parents, and madzmumah's morals include (1) gossiping, (2) suicide, (3) drinking alcohol, (4) pessimism and (5) kufr. The results of the research related to the moral values can be implemented in learning Indonesian in madrasas.
\end{abstract}

Keyword : novel, caracters, education

\section{PENDAHULUAN}

Bahasa merupakan aspek yang tidak terlepas dari kehidupan manusia. Dalam hal ini, bahasa menjadi suatu kebutuhan yang berfungsi untuk menyampaikan maksud antar individu maupun kelompok. Definisi bahasa secara istilah adalah ungkapan/bunyi yang berasal dari alat ucap manusia yang digunakan oleh kelompok/individu sosial untuk menyampaikan maksud, berkomunikasi dan mengidentifikasi diri.

Selain berupa bunyi bahasa juga dapat berupa tulisan. Hal itu terjadi karena adanya perbedaan waktu dan jarak. Seseorang dapat menerima informasi dari masa lampau atau dari tempat yang jauh melalui bahasa tulis (Chaer: 2012). Bahasa tulis pun sebenarnya merupakan rekaman bahasa lisan agar dapat disimpan dan disampaikan ulang di lain waktu dan lain tempat. Walaupun bahasa tulis merupakan rekaman dari bahasa lisan, namun terdapat perbedaan yang signifikan antara kedua jenis bahasa tersebut. Bahasa lisan diungkapkan secara langsung oleh seseorang beserta intonasi, nada dan jeda yang sesuai dengan apa yang dimaksud oleh orang yang mengucapkannya. Sementara bahasa tulis disampaikan melalui pertimbangan, pemikiran bahkan 
penghayatan seseorang terhadap pengalamannya. Sebab, kalau tanpa hal tersebut peluang terjadinya kesalahpahanman sangat besar. Bahasa tulis juga dapat menggambarkan isi hati dan pemikiran seseorang tentang permasalahan dan pengalaman dalam kehidupannya. Untuk itu bahasa tulis memiliki makna yang lebih mendalam terhadap nilai kehidupan.

Salah satu wujud dari bahasa tulis adalah karya sastra. Karya sastra merupakan ungkapan seorang sastrawan melalui teks yang mencerminkan pengalamannya menjalani kehidupan di lingkungan sosial. Masyarakat sosial sering mengalami peristiwa kehidupan yang beraneka ragam, baik yang mengandung aspek sosial, budaya, politik, ekonomi, kemanusiaan, keagamaan, maupun moral. Kehidupan masyarakat tidak terlepas dari toleransi antar sesama, hubungannya dengan penciptanya dan hubungan manusia dengan alam sekitar. Oleh karena itu, seorang sastrawan dalam menuangkan imajinasinya pada karya sastra, sangat berhubungan erat dengan fenomena yang terjadi di lingkungan hidupnya.

Pesan yang terkandung dalam karya sastra bertujuan untuk mengarahkan keadaan suatu kelompok/individu ke arah yang lebih positif (Rosita \& Ferdian, 2018). Karya tersebut dapat menginspirasi pembaca lewat cerita yang ada didalamnya. Penulisan karya sastra ditempuh oleh pengarang dalam merealisasikan bagaimana jalan tengah/solusi dalam permasalahan yang ada di lingkungan sosialnya. Oleh karena itu, karya sastra mengandung nilai-nilai postif yang dapat diaplikasikan dalam kehidupan, mulai dari individu, keluarga, masyarakat, hingga hubungannya dengan tuhan (Rahmawati \& Ferdian, 2019). Karya sastra tercipta dari seorang sastrawan yang berpengalaman dalam mengahayati kehidupan. Karya sastra yang baik adalah karya sastra yang dapat memberikan manfaat dan kesan pada pembacanya untuk berbuat yang lebih baik dan sesuai dengan ajaran agama.
Pengarang mewujudkan pesan dalam karya fiksi melalui media bahasa. Gaya bahasa pengarang merupakan sarana untuk menyampaikan buah pikiran dan imajinasinya dalam menciptakan karya sastra. Keindahan gaya bahasa dilukiskan oleh pengarang melalui suasana cerita, watak/karakter tokoh yang bermacammacam, penentuan alur dan lain sebagainya yang sesuai dengan pengalaman pengarang. Untuk itu, gaya bahasa setiap karya sastra berbeda-beda karena imajinasi setiap pengarang juga berbeda (Setyorini, 2014). Dalam hal ini, sosok pengarang membuktikan kepiawaiannya sebagai seorang sastrawan yang memunculkan imajinasi pembaca atas gaya bahasa yang digunakannya.

Novel merupakan Salah satu jenis karya fiksi. Novel menggambarkan apa yang ada dalam pikiran pengarang yang sesuai dengan realita sosial. Novel merupakan ungkapan pengarang sebagai gambaran berbagai masalah kehidupan yang dialaminya, salah satunya adalah kehidupan antar umat beragama dalam lingkup masyarakat. Hal ini bertujuan agar pembaca novel ikut merasakan dan menghayati berbagai macam warna kehidupan dan menjalani kepercayaannya di tengah peradaban lain. Seorang pengarang akan memunculkan nilai dalam karyanya ketika ia telah memperoleh pengalaman akan nilai tersebut. Pada saat itu lah imajinasi pengarang akan tertuang kedalam tulisan. Karya sastra yang diciptakan oleh pengarang pasti mengandung nilai tertentu sebagai cerminan kehidupannya yang akan disampaikan kepada pembaca.

Berbagai interaksi yang dialami manusia dominan bernilai positif jika dikemas dengan ajaran Islam. Ajaran Islam berisi tentang keyakinan seseorang atas dasar iman dalam menjalani segala interaksinya. Pada era globalisasi ini, nilai tersebut perlu ditanamkan pada masyarakat terutama kaum muda yang bergelut di bidang persekolahan. Kaum muda sebagai generasi penerus bangsa membutuhkan 
internalisasi nilai-nilai kehidupan dalam menumbuhkan jati diri yang utuh dan berintegritas untuk menjaga nama baik martabat bangsa. Penanaman nilai-nilai yang terkandung dalam novel tersebut dapat tersalur dengan baik salah satunya dengan menggunakan media pembelajaran

Ajaran Islam dapat dijadikan acuan positif dalam segala aktifitas manusia yang sesuai dengan etika kehidupan dan budaya bermasyarakat. Dalam ajaran Islam terkandung berbagai aspek yang menjamin kerukunan/perdamaian antar sesama. Hal tersebut terinci dalam dasar ajaran Islam yang mencakup sistem kepercayaan, hukumhukum Islam dan etika dalam segala interaksi. Sistem kepercayaan merupakan aspek yang secara khusus mengkaji interaksi manusia yang dipersembahkan untuk penciptanya. Hukum Islam mengkaji aspek peraturan yang mencakup segala aktifitas manusia. Sedangkan etika mencakup aspek prilaku dalam menjalankan segala interaksi tersebut.

Beberapa novel dikatakan sebagai novel religius karena banyak mengandung nilai religius (Isnaniah, 2013). Novel religius berkaitan dengan persoalan penyerahan diri, tunduk dan taat kepada tuhan. Religiusitas dalam karya sastra lebih berkaitan dengan latar belakang sastrawan dalam menghasilkan teks-teks sastra yang begitu kental dengan ajaran keagamaan dan kehidupan manusia. Menurut Ardian (2016), aspek religiositas menjelaskan tujuan kehidupan manusia. Penjelasan tersebut dapat berupa usaian, simbol maupun sejarah. Dari penjelasan yang ada, manusia akan memahami tentang etika, moral dan hukum agama yang harus mereka patuhi.

religiositas dalam karya sastra menjadi gambaran pengabdian pengarang terhadap hukum agama yang dianut kemudian ia tuangkan dalam karyanya melalui tokoh yang dapat ditiru oleh pembaca. Karya sastra yang berlandaskan dengan nila-nilai religius akan memiliki jiwa yang seakan tumbuh dalam karya tersebut karena lahir dari getaran hati nurani.
Salah satu nilai religius dalam karya sastra sesuai dengan ajaran agama islam adalah akhlak. Akhlak berasal dari kata bahasa Arab khuluk yang berarti tingkah laku, watak, etika dan budi pekerti (Munawwir, 2007: 21). Dalam bahasa Indonesia kata akhlak lebih merujuk pada etika (KBBI, 2016). Istilah etika sering digunakan untuk merumuskan sikap kejiwaan dan tingkah laku seseorang dari segi lahir maupun batin. Akhlak adalah sifat yang tertanam dalam jiwa seseorang yang secara spontan muncul jika diperlukan, tanpa memerlukan pemikiran atau pertimbangan lebih dahulu serta tidak memerlukan dorongan dari luar (Isnaniah, 2013). Kajian akhlak adalah tingkah laku manusia atau tepatnya nilai dari tingkah lakunya yang berisi nilai baik dan nilai buruk. Muhammad Daud Ali (2011: 348) merumuskan bahwa pencerminan akhlak seseorang dapat diketahui dengan meninjau beberapa syarat, yaitu dilakukan secara berulang-ulang, jika dilakukan sekali dan jarang maka belum termasuk kriteria akhlak. Kemudian timbul dengan sendirinya, tanpa adanya pertimbangan dan pemikiran, perbuatan tersebut muncul karena telah menjadi kebiasaan.

Menurut Marzuki (2012: 181-184), ruang lingkup akhlak dalam Islam mencakup lima aspek yaitu: 1) Akhlak terhadap Allah Swt. Orang Islam memiliki akidah yang benar dan kuat, berkewajiban untuk bertaqwa kepada Allah. 2) Akhlak kepada diri sendiri. Manusia dilahirkan dalam keadaan suci. Maka manuia berkewajiban menjaga kesucian tersebut dengan cara memelihara kerapihan, berjalan dan berkata dengan sopan dan tenang, menambah pengetahuan sebagai modal amal, membina kedisiplinan diri. 3) Akhlak kepada keluarga. Akhlak terhadap keluarga dapat dilakukan dengan cara berbakti kepada orang tua dan berbuat baik terhadap saudara. 4) Akhlak kepada tetangga. Saling toleran dan tidak menggunjing terhadap tetangga. 5) Akhlak terhadap lingkungan. Hasyr (dalam Marzuki: 2012) mengatakan bahwa akhlak 
seorang muslim menganjurkan agar tidak ada pengerusakan terhadap alam kecuali terpaksa dan sesuai ketentuan Allah sehingga tidak keluar dari fungsi dan tujuan penciptaan.

Taufik dan Rohmadi (2010: 55-56) menyatakan bahwa ciri akhlak dalam Islam terbagi menjadi lima aspek, yaitu (1) kebaikannya bersifat mutlak, dalam arti murni bagi individu maupun kelompok dalam segala keadaan dan tempat (2) kebaikannya bersifat menyeluruh, kebaikan yang terkandung merupakan kebutuhan seluruh umat manusia (3) bersifat tetap dan langgeng meskipun zaman sudah berubah (4) berbentuk kewajiban yang harus dipenuhi, yang berarti kebaikan tersebut merupakan hukum yang harus dilaksanakan dan (5) berwujud pengawasan yang menyeluruh, akhlak Islam bersumber dari tuhan, maka seseorang akan menyesali perbuatan buruknya karena ada sangsi yang harus dipertanggungjawabkan kelak.

Zainuddin dan Jamhari (1999: 77) merumuskan secara rinci dari penjelasan tentang akhlak di atas ke dalam dua bagian yaitu akhlak mahmudah (akhlak terpuji) dan akhlak madzmumah (akhlak tercela). Akhlak mahmudah merupakan suatu pertanda atau sifat yang mewakili atas sempurnanya iman seseorang. Dalam hal ini, pembagian akhlak tersebut dapat ditinjau dari segi tujuannya, yaitu untuk mendapatkan ridha dari Allah SWT, membentuk kepribadian muslim dari segi ucapan, tindakan dan prasangka yang mencermirkan ajaran Islam dan untuk mewujudkan sikap yang mulia serta terhindar dari sikap yang tercela.

Imam Al-Ghazali dalam kitab ihya' ulumuddin (dalam Zainuddin dan Jamhari, 1999: 78) menjelaskan bagaimana prilaku yang tercermin dari hati yang sehat merupakan akhlak mahmudah. Sementara akhlak madzmumah adalah prilaku tercela yang merusak iman dan menjatuhkan martabat manusia. Segala perbuatan yang bertentangan dengan akhlah mahmudah merupakan bentuk dari akhlak madzmumah. Isnaniah (2013) menyatakan bahwa akhlak madzmumah terdorong oleh empat aspek sifat, (1) sifat rububiyah yaitu sifat yang berkehendak untuk menguasai, (2) sifat syaitaniyah (kesetanan), dari sifat ini muncul prilaku dengki, mungkar, penipuan dan kemunafikan, (3) sifat bahimiah (kebinatangan), dari sifat ini muncul sikap rakus, tidak terkendalinya hawa nafsu yang menimbulkan perzinaan, pencurian dan penghardikan pada anak yatim (4) sifat sabu'iyah (kebuasan), sifat ini menimbulkan terjadinya tawuran, pembunuhan bahkan perusakan fisik dan harta benda.

Salah satu novel yang kaya akan nilai ajaran Islam adalah novel Iam Sarahza Karya Hanum Salsabiela dan Rangga Almahendra. Novel ini merealisasikan pengalaman pengarang dengan mengedepankan ajaran Islam. Ajaran Islam perlu ditanamkan pada ideologi masyarakat untuk menciptakan perdamaian antar umat beragama. Dengan adanya penanaman ajaran Islam tersebut, diharapkan dapat membuka sisi positif yang dapat dipetik dari cerita dalam novel Iam Sarahza. Peneliti tertarik untuk meneliti dan membahas mengenai ajaran Islam yang terdapat dalam novel I am Sarahza. Peneliti juga memanfaatkan media novel tersebut sebagai bahan ajar pendidikan Bahasa Indonesia di Madrasah.

Novel I am Sarahza ini belum pernah diteliti sebelumnya. Namun ada beberapa penelitian yang relevan yang menganalisa nilai-nilai kehidupan serta mengaimplikasikannya pada pembelajaran dengan objek novel. Untuk menghindari terjadinya plagiarisme, peneliti akan paparkan beberapa penelitian yang pernah mengkaji hal yang sama untuk dijadikan perbandingan dan relevansi. diantaranya sebagai berikut.

Penelitian yang relevan dengan penelitian ini yakni skripsi yang ditulis oleh Ariyadih (2013) dengan judul "Nilai-Nilai Religius dalam Novel Opera Van Gontor karya Amroeh Adiwijaya dan Implikasinya terhadap Pembelajaran Sastra di Sekolah". 
Dalam hal ini peneliti mengungkapkan tentang isi atau nilai-nilai religius yang ada dalam novel Opera Van Gontor, kemudian menafsirkan implikasinya dengan sastra. Hasil penelitiannya menunjukkan: Nilainilai religius yang terkandung dalam novel Opera Van Gontor adalah (a) penyerahan diri dan tunduk kepada Allah. (b) Kehidupan yang penuh kemuliaan, (c) perasaan batin yang ada hubungannya dengan tuhan, (d) Perasaan berdosa, (e) Perasaan takut dan (f) Mengakui kebesaran tuhan. Persamaan dalam penelitian tersebut adalah aspek kajian dalam nilai religius. Sedangkan perbedaannya adalah bidang kajian aspek religiunya. Penelitian pada novel Opera Van Gontor ini, secara langsung mengkaji aspek religius yang telah ditentukan tanpa mengkaji dasar-dasar ajaran agama Islam. Sedangkan dalam penelitian yang peneliti lakukan mengkaji nilai akhidah Islam dalam novel Iam Sarahza dengan teori-teori yang menjadi dasar-dasar ajaran agama Islam.

\section{METODE PENELITIAN}

Penelitian ini termasuk deskriptif kualitatif. Dalam penelitian ini, terdapat dua teknik yang ditempuh oleh peneliti untuk memperoleh data, yaitu teknik baca dan tenik catat. Teknik baca dilakukan dengan cermat dalam mengamati bentuk yang ada dalam teks novel I am Sarahza. Pembacaan dilakukan secara berulang-ulang guna memperoleh data secara detail. Teknik Catat dilakukan dengan mencatat kutipan pada teks novel yang berkaitan dengan fokus penelitian dari hasil pengamatan, kemudian dilakukan inventarisasi data sebagai bahan yang akan diolah dalam penelitian, sumber data utama yaitu teks novel I am Sarahza Karya Hanum dan Rangga. Dalam penelitian ini, peneliti menerapkan triangulasi teori. Peneliti menggunakan perspektif lebih dari satu teori untuk membahas permasalahan yang dikaji berupa unsur intrinsik karya sastra dan ajaran Islam. Teori-teori tersebut akan mempermudah peneliti untuk memahami permasalahan yang dikaji dalam penelitian. Dalam penelitian ini, peneliti menggunakan teknik analisis isi. Operasional awal teknik ini adalah memberi tanda terhadap data yang terkait dengan analisis. Kemudian peneliti mengkategorikan data sesasui dengan kajian, baru dilakukan analisis dengan cara menafsirkan data yang telah ditandai dan dikategorikan (Kusaeri, 2010: 123).

\section{HASIL DAN PEMBAHASAN \\ Representasi Akhlak dalam novel I Am Sarahza}

\begin{abstract}
Akhlak Mahmudah
Akhlak mahmudah merupakan suatu pertanda atau sifat yang mewakili atas sempurnanya iman seseorang. Dalam hal ini, pembagian akhlak tersebut dapat ditinjau dari segi tujuannya, yaitu untuk mendapatkan ridha dari Allah SWT, membentuk kepribadian muslim dari segi ucapan, tindakan dan prasangka yang mencermirkan ajaran Islam serta mewujudkan sikap yang mulia serta terhindar dari sikap yang tercela. berikut pembahasan akhlak dalam novel $I \mathrm{am}$ Sarahza.
\end{abstract}

\section{a) Sopan}

Sikap tokoh Rangga yang sopan dan tidak menyinggung lawan bicaranya Hal tersebut dirasakan pula oleh berbincang dengan Rangga.

"terus terang aku belum pernah bertemu dengan pemuda yang cukup sopan dan tidak money oriented seperti Rangga. Ia tidak seperti orang-orang yang merubungku dan tanpa ba-bi-bu menjajali dengan proposal pembiayaan kampanye" (Hanum dan Rangga, 2018: 32)

Kutipan di atas menunjukkan sikap Rangga yang sopan dan ramah. Hanum mengungkapkan bahwa saat pertama kalinya berbincang dengan Rangga, Hanum merasakan sikap Rangga yang tanpa basabasi berbicara pada lain perkara, ia berbicara 
langsung pada inti pembicaraan. Bentuk sikap Rangga yang sopan juga tampak saat ia memanggil Hanum pertama kalinya dengan sebutan "mbak". Sebutan tersebut ebagai ungkapan rasa hormat Rangga pada lawan bicaranya yang baru ia kenali (Hanum dan Rangga, 2018: 28). Kemudian ungkapan maaf Rangga sebagai ungkapan sopan saat ia hendak mengajukan pertanyaan pada Hanum (Hanum dan Rangga, 2018: 31).

\section{b) Ikhlas}

Rangga mengeluarkan biaya yang tidak sedikit serta harus meluangkan banyak waktu untuk mendampingi Hanum dalam program inseminasi ketiga. Ia ikhlas dengan segala keputusan yang diterimanya setelah 12 hari masa tunggu.

\section{"ayah tampak ikhlas, ikhlas energi, waktu, dan dana. Ikhlas inseminasi telah memberangus ketiga-tiganya. Hari ini setelah 12 hari masa tunggu, ayah dan ibu wajib menghadap Herz untuk mendapatkan jawaban atas penyebabnya" (Hanum dan Rangga, 2018: 101).}

Kutipan yang di ungkapkan oleh sarahza di atas menggambarkan keiklasan Rangga dalam mendampingi Hanum. ketika Hanum menjalankan program inseminasi, Rangga dengan ikhlas merelakan tenaga, waktu dan tenaga yang dimilikinya. 12 hari bukanlah waktu yang sebentar, Selama itu Rangga selalu mendampingi Hanum. sebagai seorang suami yang menunjukkan kasih sayangnya, keikhklasan Rangga patut untuk di contoh para pembaca.

\section{c) Sabar}

Rangga mencoba menenangkan Hanum yang sedang terluap emosi akibat kegagalan program bayi tabung. Rangga meletakkan tally counter tasbih di meja kamar mereka berdua agar Hanum senantiasa mengingat Allah dan merasa lebih baik.

\footnotetext{
"Menangislah num, jika itu membuatmu lebih tenang. Tapi pegang
}

ini. Agar kamu merasa lebih baik." Kuletakkan tally counter tasbih yang kugenggamkan dulu setiap hanum digeledek ke ruang operasi. (Hanum dan Rangga, 2018: 162).

Kutipan di atas menunjukkan sikap Rangga yang sabar menghadapi Hanum. Hanum mengalami depresi yang mengundang emosinya. Rangga sebagai sang suami mengambil tindakan yang bijaksana. Kesabaran Rangga membuat pikirannya tenang dan tepat dalam mengambil keputusan. Saat Hanum dilanda emosi, Rangga meletakkan counter tasbih agar Hanum senantiasa mengingat Allah. Hal tersebut juga merupakan suatu sindiran bagi Hanum bahwa marah tak terkendali merupakan rayuan setan dan merupakan tindakan yang tidak di sukai oleh Allah. Sikap Rangga menunjukkan kesabaran yang patut di contoh oleh orang lain. Kesabaran Rangga selalu di uji oleh Allah ketika hanum mendapatkan kabar kegagalan atas program kehamilan yang diikutinya, dan Hanum tak pernah mendengar Rangga mengeluh sekalipun (Hanum dan Rangga, 2018: 188).

\section{d) Menyantuni anak yatim}

Hanum berencana untuk menyantuni anak yatim di panti asuhan Muhammadiyah. Dengan cara mengadakan pengajian.

"say, aku berandai-andai dengan jumlah bonus dan royalty yang cukup besar ini. Kemudian Hanum menjawab "iya mas. Aku rencana mau ngadain pengajian rutin untuk anak yatim di panti asuhan Muhammadiyah. Biar bonusnya berkah." (Hanum dan Rangga, 2018: 180)

Rangga mengungkapkan keinginan dari penghasilan pembuatan film. Hanum pun meresponnya dengan memanfaatkan hasil tersebut untuk santunan anak yatim. Namun, bukan hal tersebut yang menjadi keinginan Rangga melainkan mengikuti program kehamilan bagi Hanum (Hanum dan Rangga, 2018: 180). Karena niat 
Hanum yang baik, yaitu menyantuni anak yatim, Rangga pun menyetujui saran tersebut dengan tujuan mencari keberkahan terhadap segala harta yang dimilikinya.

Santunan yang dilakukan Hanum dan Rangga berupa nominal yang dibungkus dengan amplop. Selain itu, Hanum juga menghibur anak-anak yatim dengan berdongeng (Hanum dan Rangga, 2018: 282). Menyantuni anak yatim merupakan perbuatan yang mulia. Rasulullah mengibaratkan jari tengah dan jari telunjuk bagi dirinya dan orang-orang yang menyantuni anak yatim. Perbuatan tersebut berdampak pada kessejahteraan hidup manusia dan kerukunan antar sesama.

\section{e) Sukur}

Rasa sukur Hanum yang mendapatkan kabar bahwa peluang untuk ia hamil setelah mengikuti program bayi tabung lebih besar dari peluang kegagalannya.

"ibu bangkit dari sujudnya. Lalu ia meneriakkan pengumuman itu kepada seluruh pengunjung restoran. Seperti tidak bisa mengontrol gejolak bahagia, ibu masuk ke dapur restoran, mengeluarkan beberapa lembar uang 50 ribuan an memberi salam temple kepada seluruh pelayan."(Hanum dan Rangga, 2018: 190)

Dari ungkapkan Sarahza tersebut,
dapat diketahui bahwa Hanum mengungkapkan rasa sukurnya dengan menyedekahkan harta yang dimilikinya dan tindakan sujud sukur yang dilakukannya. Sukur dapat di ungkapkan dengan berbagai cara. Ungkapan sukur yang paling dasar adalah dengan mengucapkan lafad Alhamdulillah. Pada kutipan di atas, Hanum menunjukkan betapa bersukurnya ia mengetahui bahwa dirinya bisa mengandung dan harapan besar memiliki buah hati dapat tercapai. Peristiwa di atas memberikan respon yang positif bagi pembaca novel. Perilaku-perilaku yang positif dapat diungkapkan dengan segala sesuatu yang kita sanggup lakukan. Penghargaan atas pemberian Allah adalah cerminan dari akhlak yang mulia.

f) Sedekah

Saat Rangga beristirahat di tepi persawahan, tepi gunung merapi, ia melihat kakek tua bersarung dan menggendong kayu diatas punggungnya sembari menggandeng tangan istrinya yang renta menuntun sepeda berisi padi (Hanum dan Rangga, 2018: 263). Kemudian Rangga memberikan dua lembar uang kepada mereka.

"ku hampiri mereka dan ku cegat. Dua lembar rupiah bergambar Soekarno ku ulurkan."(Hanum dan Rangga, 2018: 263)

Dari kutipan di atas, tampak sikap Rangga yang dermawan terhadap orang lain tanpa memandang latar belakang kehidupan orang tersebut. Rangga hanya mengetahui aspek sosial dari kedua orang tua yang melewatinya. Sedangkan aspek yang lain pun masih banyak, entah itu aspek agama, moral dan aspek lain yang melatar belakanginya. Sedekah yang diberikan Rangga jelas tanpa mengharap balasan apapun dari penerimanya, ia berniat untuk membantu segi ekonomi orang tersebut. Tanpa Rangga sangka, perbuatan tersebut berdampak pada ridho Allah untuk Hanum memiliki buah hati. Kedua orang tua tersebut memasukkan satu lembar uang yang di berikan Rangga ke dalam kotak amal masjid seraya mendoakan agar Hanum dan Rangga diberi keturunan (Hanum dan Rangga, 2018: 343).

Dari uraian di atas, dapat diketahui bahwa perbuatan baik akan berbalas baik tanpa disangka-sangka. Pembaca novel Iam Sarahza dapat menggali pelajaran yang terkandung dalam peristiwa tersebut serta mengaplikasikannya dalam kehidupan bermasyarakat.

\section{g) Menasehati}

Saat bapak Hanum dan hanum berjalan-jalan disepanjang komplek perumahan yang dipenuhi oleh ibu-ibu yang mengantarkan anaknya ke sekolah, bapak hanum 
menasehati hanum dengan memberi pembelajaran yang sangat berharga.

"satu, jaga shalatmu, shalat itu dibilang tiang agama tapi juga tiang hidup seseorang, kamu bisa terseret angin terpelanting terombang ambing tapi selama tiangmu kuat, peganganmu kuat, InsyaAllah kamu baik-baik saja....."

"dua, Al-Qur'an itu dibaca dan diresapi jangan hanya dijadikan pajangan rak. Dibaca nyaring biar aura rumahmu terkena sinarya, rasanya ditubuh juga lebih plong lega. Malaikat juga berbondong-bondong mendengarkan. Al-Qur'an itu obat dan sahabat....."

"tiga, gunakan waktu luang bahkan ketika kamu melamun dengan dzikir. Kalau bapak, paling suka tahlil dan istighfar. Dzikir yang sepenuh hati disusupkan ke liang-liang kalbu."(Hanum dan Rangga, 2018: 269-270)

Dari kutipan di atas, bapak Hanum bertujuan untuk meneguhkan Hanum dalam segala keadaan yang ia alami. Keadaan yang membuatnya drop bapak Hanum menasehati agar Hanum senantiasa berpegang teguh pada ajaran agama Islam, selalu berdzikir dan memohon pada Allah. Atas nasehat yang diberikan bapaknya yang seketika Hanum menurut nasehat tersebut membuat Hanum lebih tenang dan menerima segala yang Allah berikan dengan ikhlas tanpa menyalahkan segala sesuatu yang orang lain bahkan menyalahkan Allah.

\section{h) Membuang sampah pada tempatnya}

Rangga melihat sampah yang berceceran, kemudian ia menyuruh Hanum untuk memungutnya dan membuangnya di tong sampah.

"sampahnya dibuang di tong ya! Jangan berceceran kayak gini nih.”(Hanum dan Rangga, 2018: 281)

Kutipan di atas mengajarkan bagi setiap orang untuk menjaga kebersihan lingkungan yang menciptakan kenyamanan. membuang sampah pada tempatnya dapat menghindarkan diri manusia dari bencanabencana yang mungkin terjadi seperti banjir. Kenyamanan akibat terhindar dari aroma sampah yang mengusik pernapasan juga dapat terwujud. Hal tersebut dapat di aplikasikan dalam kehidupan di masyarakat agar terwujud keadaan lingkungan yang bersih.

i) Berbakti pada orang tua

Rangga menyatakan kontrak berbakti kepada orangtua sepanjang hayat dengan peristilahan tanda tangan di atas kertas.

"kami sudah kadung menandatangani kontrak untuk berbakti kepada orangtua sepanjang hayat."(Hanum dan Rangga, 2018: 314)

Kutipan di atas mengajarkan pada setiap orang untuk berbakti pada orang tua. Bakti tersebutt tidak terbatas ruang dan waktu, di kala berkehidupan jauh dari orang tua, sebagai cerminan kebaktian seoarang anak, hendak lah ia senantiasa mendoakan orang tuanya. Sementara masa kebaktian tersebut adalah sepanjang hayat. Hal tersebut yang di pegang teguh oleh Rangga dalam menjaga kerukunan antar anggota keluarga. Prinsip Rangga dalam menghormati kedua orang tuanaya merupakan cerminan dari akhlak mulia pada diri Rangga yang memberi nilai positif bagi kehidupan berkeluarga.

Akhlak mahmudah merupakan perbuatan terpuji yang menciptakan kerukunan dalam masyarakat. Dalam novel Iam arahza terdapat beberapa peristiwa tokoh yang menggambarkan akhlak mahmudah, di antaranya adalah prilaku sopan, ikhlas, sabar, menyantuni anak yatim, sukur, sedekah, menasehati, membuang sampah pada tempatnya dan berbakti kepada orang tua. Prilaku-prilaku tersebut termasuk dalam kategori akhlak mahmudah karena bertujuan untuk mewujudkan suasana masyarakat yang rukun dan nyaman. Prilaku terebut dapat di contoh oleh pembaca dalam 
rangka pembentukan karakter yang baik dan sesaui dengan ajaran agama Islam.

\section{Akhlak Madzmumah}

\section{a) Menggunjing}

Sifat menggunjing dilakukan oleh orangorang di sekitar habum saat ia datang untuk memenuhi koas perkuliahan di fakultas kedokteran gigi UGM. Beberapa hari setelah pilpres, Hanum kembali menuju kampus untuk memenuhi koas perkuliahannya. Namun tanpa ia sangka, orang disekitarnya mengucapkan kata-kata yang menyindir perasaan yang membuat Hanum semakin sedih.

\footnotetext{
"kalah nih ye... kalah nih ye.." salah satu kolega mengucapkannya sambil menghadap tembok.

"kalau lu kalah main gaple tadi malem, nggak usah masuk kampus dulu. Pakai acara pidato kekalahan segala. Tidur sana, nangis dulu! Kalau strees bisa bahaya tuh pasien" (Hanum dan Rangga, 2018: 39-40)
}

Kutipan di atas menunjukkan sikap yang menyinggung perasaan seseorang. Mendengar singgungan orang-orang di kampus tersebut, Hanum berusaha untuk menghindar dengan lari menjauh mencari tempat yang sepi. Ia meluapkan rasa sedih yang menyelimutinya hingga ia meneteskan air mata (Lamp. Iam Sarahza: 40). Perbuatan tersebut berakibat pada perasaan dan kenyamanan seseorang dalam hal bertoleransi antar sesama. Hal tersebut menjadi pelajaran bagi pembaca novel untuk mengetahui prilaku-prilaku yang tercela dan menghindarinya. Islam mengajarkan untuk hidup rukun dan bertoleran.

\section{b) Bunuh Diri}

Perlakuan bunuh diri dilakukan oleh suami seorang nenek yang sedang duduk di samping Hanum. Kemudian Hanum mengobrol dengan nenek tersebut. Nenek itu menceritakan perbuatan suaminya yang tidak patut dicontoh oleh siapapun, karena perbuatan tersebut berakibat memutukan masa depan yang belum kita ketahui dan masih bisa diperbaiki.

"sebelum akhirnya datang sebuah kabar buruk. Ia bunuh diri di rel kereta setelah mabuk. Dia sangat terpukul dan merasa tak berguna sebagai laki-laki karena diberhentikan kantor padahal pemecatan itu bukan kesalahannya. Tapi kantor memang sedang mengurangi pegawai." (Hanum dan Rangga, 2018: 76)

Bunuh diri merupakan prilaku yang dilarang dalam Islam. bunuh diri bukan solusi dari berbagai permasalahan kehidupan. Bisa jadi bunuh diri merupakan malapetaka bagi kehidupan seseorang yang mendapatkan dampaknya. Pada kutipan di atas, diketahui bahwa bunuh diri dilakukan oleh seorang kepala keluarga, yang berdampak negatif pada anggota keluarganya, anaknya terancam hidup yatim dan tidak ada jaminan kebutuhan hidup bagi istrinya. Prilaku tersebut merupakan cerminan keputusasaan tanpa didampingi usaha yang berkemungkinan dapat merubah kehidupannya lebih baik di masa depan.

\section{c) Meminum Alkohol}

Hanum bertemu dengan teman kolega seruangan. Tetapi hanum mengeluh karena bau mulut caterina yang menyeruakan alkohol dan rokok padahal caterina sedang mengandung. Alkohol dapat berakibat pada hilangnya kesadaran seseorang. Perbuatan yang tidak kita sadari dan bertentangan dengan norma kemanusiaan bisa saja dilakukan karena secara tidak sadar, seseorang yang kehilangan kesadaran tidak dapat mengontrok fisiknya sendiri.

"Hanum sering menemuinya untuk kemudia bertanya-tanya tentang program kehamilan yang dijalani caterina. Meski Hanum selalu mengeluh bau mulut Katerina kerap menyuarakan alkohol dan rokok di masa kehamilannya."( Hanum dan Rangga, 2018: 90) 
Dalam Islam, meminum alkohol berhukum haram, karena alkohol dapat menghilangkan kesadaran akal peminumnya. Pengaruh pada kesehatan fisik pun juga berdampak negatif. Untuk itu, pembaca novel dapat mengetahui hal-hal yang merugikan bagi kesehatan tubuh dan perkara apa saja yang di larang dalam ketentuan agama.

\section{d) Pesimis}

Hanum merasa menyalahkan tuhan, ia menganggap bahwa tuhan tak sedikitpun menoleh padanya, padahal hanum sudah berusaha mati-matian. Hanum pun menganggap bahwa tuhan telah memberikan canda yang menusuk yang membuatnya sebal dan marah.

\begin{abstract}
"tuhan pun sombong padaku. Tak mau menoleh padaku, meski aku telah berjuang mati-matian sepuluh tahun lebih! Tak lelahnya aku menunjukkan bahwa aku peduli pada-Nya. Dengan bukuku, dengan filmku, dengan semua shalat, puasa, sedekah dan seluruh ibadahku! Bahkan sedikitpun aku tak tergoda untuk mencari dukun dan paranormal untuk menujum kehamilanku" (Hanum dan Rangga, 2018: 234) "kegagalan kali ini begitu menyakitkan, sebab tuhan telah menitipkan canda yang menusuk. Aku tidak suka canda ini" (Hanum dan Rangga, 2018: 236).
\end{abstract}

Dalam kutipan di atas, Hanum seolaholah menyalahkan ketentuan tuhan. Ia menganggap bahwa tuhan tidak adil. Hal tersebut ia ungkapkan saat dirinya diredam depresi atas kegagalan program kehamilan untuk kesekian kalinya. Cobaan Allah pasti tidak melebihi kuasa makhluknya. Namun, Hanum terlanjur berfikir pesimis atas ketentuan tersebut. Pesismis bukan hanya berarti tidak percaya diri saja, melainkan berfikir negative atas ketentuan merupakan ranah pesimis. Pesimis membuat seseorang berfikiran yang merugikan dirinya sendiri.
Islam mengajarkan untuk selalu optimis dalam segala ketentuan Allah.

\section{e) Kufur}

Hanum terkejut melihat berat badannya yang naik drastis menjadi $64 \mathrm{~kg}$. ia membandingkan dengan kondisi fisiknya 12 tahun lalu saat menjadi dokter gigi. Hanum seraya mengutuk dirinya endiri karena kondisi fisik yang tidak menawan lagi.

"aku turun dari timbanagan badan
seraya mengutuk diriku sendiri. Ku
gigiti ujung jariku. Enam puluh empat
kilo gram? Aku mengingat-ngingat
kapan terakhir kali memiliki berat
badan ideal. 10 tahun lau saat aku
masih menjadi presenter TV. 12 tahun
lalu saat aku masih menjadi dokter
gigi."( Hanum dan Rangga, 2018:
233).

Kutipan si atas menunjukkan sikap yang tidak bersukur atas pemberian Allah. Hanum memiliki kondisi fisik yang tidak lagi ideal menurutnya. Namun, kodisi tersebut meskinya di sukuri oleh Hanum karena masih diberi kesehatan oleh Allah. Kufur sendiri merupakan perbuatan yang di larang oleh Allah. Seperti pada firmannya, Allah akan menmbah rezeki bagi orangorang yang mensukuri nikmatnya dan mencegah rezeki bagi orang yang kufur atas nikmatnya.

Uraian tantang akhlak madzmumah di atas mengajarkan kepada pembaca bahwa perbuatan yang dilarang dalam agama Islam yang merugikan diri diri sendiri dan orang lain bahkan masyarakat umum. Dalam novel Iam Sarahza, ditemukan beberapa konteks cerita yang menunjukkan prilaku tercela, di antaranya adalah prilaku menggunjing yang menyinggung perasaan orang lain, bunuh diri yang mengakibatkan terlantarnya anggota keluarga, meminum alkohol yang berakibat merusak fisik, pesimis yang berakibat menyalahkan takdir tuhan dan prilaku kufur yang menyebabkan keserakahan. Beberapa prilaku tersebut 
merupakan kajian dalam aspek akhlak madzmumah yang perlu diketahui oleh para pembaca untuk membatasi dirinya dalam bersikap.

\section{Relevansi Novel I am Sarahza dengan Pembelajaran Bahasa Indonesia di Madrasah Aliyah}

Pembelajaran Bahasa Indonesia di Madrasah Aliyah diprogramkan untuk membina dan mengembangkan potensi kreatif siswa karekter sesuai dengan ajaran agama Islam. Ajaran Islam yang terkandung dalam novel Iam Sarahza dapat direlevansikan dengan pembelajaran Bahasa Indonesia dalam tujuan pembangunan karakter tersebut. Hal ini berbanding lurus pada dua aspek penilaian dalam kurikulum yang berlaku, yaitu pada kompetensi inti (KI) 1 yang menerapkan pengamalan dan pengamalan terhadap ajaran agama yang dianut oleh peserta didik dan KI 2 yang menerapkan pengamalan dan penerapan dalam berprilaku jujur, santun, toleran, peduli dan akhlak terpuji lainnya. KI 3 menerapkan aspek pengetahuan yang dapat diambil dari setiap objek pembelajaran dan KI 4 menerapkan aspek keterampilan yang menunjang kemampuan siswa dalam setiap bakat yang dimilikinya.

Aspek sikap pada KI 2 dapat diaplikasikan melalui akhlak. Akhlak mahmudah untuk dicontoh oleh siswa supaya menerapkannya dalam kehidupan sehari-hari. Hasil penelitian akhlak mahmudah dalam novel Iam Sarahza berupa sikap sopan yang dapat diaplikasikan oleh siswa dalam menghormati sesama umat manusia baik pada lingkungan keluarga, sekolah maupun masyarakat umum, sikap ikhlas memberi pelajaran bagi siswa untuk menjalankan segala perintah Allah dalam berbagai aktifitas yang dilakukannya agar terhindar dari keluhan dan rasa keterpaksaan, sikap sabar sebagai pedoman bagi siswa bahwa Allah telah menentukan bahwa setelah terlewatinya kesusahan pasti akan muncul kebahagiaan. Menyantuni anak yatim merupakan perintah yang tertera dalam hais nabi, sukur menghindarkan dari sikap rakus dan murka, sedekah merupakan tabungan kehidupan di akhirat, menasehati mendrong siswa untuk melaksanakan nasehat guru dan orang tua, membuang sampah pada tempatnya menciptakan lingkungan yang bersih di lingkungan sekolah dan masyarakat, berbakti kepada orang tua dapat menciptakan Susana kekeluargaan yang rukun. Sementara akhlak madzmumah berupa menggunjing, bunuh diri, meminum alcohol, pesimis dan kufur adalah sikap yang di luar batas yang di ajarkan dalam Islam dengan tujuan untuk diketahui oleh siswa sebagai pembatas baginya dalam bersikap.

KI 3 yang menerapkan pengetahuan dapat ditempuh dengan adanya ajaran-ajaran Islam berupa akidah, syariat dan akhlak dan semua uraian dari ketiga aspek tersebut yaitu ilahiyat, ruhaniyat, nubuwat dan samiyat yang terangkum dalam akidah, ibadah (mahdah dan ghoiru mahdah) dan muamalah yang terangkum dalam syariah dan akhlak terpuji serta akhlak tercela yang terangkum dalam aspek akhlak. Uraian tersebut belum banyak diketahui pada kalangan masyarakat awam. Untuk itu, aspek pengetahuan dapat direlevansikan melalui hasil penelitian. Kemudian pengetahuan akan kesusastraan dengan adanya unsur intrinsik berupa tema, alur, latar, tokoh, gaya bahasa, sudut pandang dan amanat yang dikaji oleh peneliti.

Sementara KI 4 dapat teraplikasi dengan keterampilan membaca karya sastra bagi siswa yang bertujuan menyerap pesan yang terkandung di dalamnya serta menunjang minat dalam keterampilan menulis untuk mencipta karya sastra khususnya novel yang bernuansa religi sebagai relevansi cerita yang terdapat dalam novel Iam Sarahza. Dalam keterampilan berbicara, siswa dapat menyampaikan ulang kepada siswa lain terkait isi cerita yang terdapat dalam novel Iam Sarahza dan keterampilan menyimak dapat diimplikasikan oleh siswa yang 
mendengarkan dan menyimak penyampaian kembali cerita tersebut.

\section{PENUTUP}

Dari kajian yang dilakukan peneliti mengenai representasi ajaran Islam dalam novel Iam Sarahza karya Hanum Salsabiela dan Rangga Almahendra serta relevansinya dengan pembelajaran Bahasa Indonesia di Madrasah Aliyah, dapat diambil kesimpulan sebagai bahwa, Akhlak terbagi menjadi dua jenis, yaitu akhlak mahmudah dan akhlak madzmumah. (1) akhlak mahmudah meliputi prilaku sopan, ikhlas, sabar, menyantuni anak yatim, sukur, sedekah, menasehati, membuang sampah pada tempatnya dan berbakti kepada orang tua. (2) akhlak madzmumah melputi prilaku menggunjing yang menyinggung perasaan orang lain, bunuh diri yang mengakibatkan terlantarnya anggota keluarga, meminum alkohol yang berakibat merusak fisik, pesimis yang berakibat menyalahkan takdir tuhan dan prilaku kufur yang menyebabkan keserakahan.

Relevansi hasil penelitian dengan pembelajaran Bahasa Indonesia di Madrasah Aliyah. Relevansi ajaran Islam dalam novel Iam Sarahza dengan pembelajaran bahasa Indonesia di madrasah Aliyah dapat ditempuh melalui kompeteni inti (KI) yang tersedia. Misalnya pada KI 2 aspek sikap

\section{DAFTAR PUSTAKA}

Ardian, Iwan. 2016. Konsep Spiritualitas Dan Religiositas Dalam Konteks Keperawatan Pasien Diabetes Mellitus Tipe 2. Jurnal Keperawatan Dan Pemikiran Ilmiah. Volume 2. Nomor 5. Tahun 2016.

Chaer, Abdul. 2012. Linguistik Umum. Jakarta: PT Rineka Cipta. dapat direlevansikan dengan akhlak mahmudah berupa sopan, ikhlas, sabar, menyantuni anak yatim, sukur, sedekah, menasehati, membuang sampah pada tempatnya, berbakti pada orang tua dan akhlak madzmumah berupa menggunjing, bunuh diri, minum alkhohol, pesimis dan kufur yang bertujuan untuk diketahui siswa sebagai batasan dalam bersikap.

KI 3 aspek pengetahuan dapat direlevansikan dengan uraian ajran Islam berupa uraian akidah, syariah dan akhlak serta unsur intrinsik berupa tema, alur, latar, tokoh, sudut pandang, gaya bahasa dan amanat yang dikaji oleh peneliti.

KI 4 aspek ketrerampilan dapat direlevansikan dengan keterampilan berbahasa berupa membaca karya sastra dan mencipta karya sastra. Menyampaikan kembali cerita dan menyimak cerita dalam novel Iam Sarahza. Dalam kompetensi inti tersebut, pendidik dapat menyertakan ajaran Islam dalam novel Iam Sarahza sehingga dapat membentuk karaktersiswa yang Islami.

Uraian di atas menyimpulkan hasil penelitian tentang ajaran Islam yang terkandung dalam novel Iam Sarahza berupa aspek akhlak yang membuktikan bahwa novel tersebut bersifat religius yang dapat memberi pembelajaran kepada pembaca serta membentuk yang karakter sesuai dengan ajaran Islam.

Hanum dan Rangga.2018. Iam Sarahza. Jakarta: Republika.

Isnaniah.2013.Representai Ajaran Islam Dalam Novel-Novel Karya Habiburrahman

ElSirazy.Yogyakarta: CV. Idea sejahtera.

Kusaeri.2012.Metodologi Penelitian. Surabaya: Government of Indonesia 
Mashuda \& Inderasari: Representasi Akhlak ....

(GoI) and Islamic Development Bank (IDB).

Marzuki. 2012. Pembinaan Karakter Mahaiswa Melalui pendidikan Agama Islam. Yogyakarta: Penerbit Ombak

Rahmawati, E., \& Ferdian, A. (2019). NilaiNilai Moral Novel Peter Karya Risa Saraswati dan Relevansinya dengan Pembelajaran Bahasa. Lingua Franca: Jurnal Bahasa, Sastra, Dan Pengajarannya, 7(1), 52-64.

Rosita, F. Y., \& Ferdian, A. (2018). Pendidikan Karakter Dalam Novel Cinta 2 Kodi Karya Asma Nadia. Alayasastra, 14(1), 55-71.

Setyorini, Nurul. 2014. Aspek-aspek Stilistika Novel Lallita Karya Ayu Utami. Prosiding Seminar Nasional
Pembelajaran Bahasa untuk Meningkatkan Kualitas Manusia Indonesia yang berkarakter falam Era Mondial".http://ejournal.umpwr.ac.id. (Diakses Pada 02 September 2017).

Taufiq, Ahmad dan Rohmadi. 2010. Pendidikan Agama Islam: Pendidikan Karakter Berbasis Agama. Surakarta: Yuma Pressindo.

Daud, Ali Muhammad.2011.Pendidikan Agama Islam.Jakarta: Raja Grafindo Persada.

Al-Munawir, A. warson.2007. Kamus AlMunawir Indonesia-Arab terlengkap. Surabaya: Pustaka progressif

Zainudin dan Muhammad Jamhari. 1999. AlIslam 2: Muamalah dan Akhlak. Bandung: CV Pustaka Setia. 